STOYATSKA GANNA,

Dnipropetrovsk State University of Internal Affairs (Dnipro, Ukraine)

e-mail: a.sagdianna@gmail.com,ORCID 0000-0002-6501-6703

\title{
AMBIVALENCE OF METAPHORICAL THINKING IN THE CONTEXT OF SEARCH FOR SENSES
}

The paper discloses the question of ambivalent character of the metaphor as means of expression of the meaning. The metaphor appears as effective phenomenon in cognitive process. At the same time, in particular philosophical texts the metaphor can reduce the subject of the research and bring self-contradictory meanings. The author's position consists in the idea that in general the metaphor is not effective means for the practical research, however, the metaphorical argumentation reveals the dual character of social or historical phenomena. The author demonstrates the functioning of the social metaphors with examples of the works of T. Hobbes, J. Locke, K. Marx and shows that they can be reconsidered conceptually in the light of context of the use. Depending on the such context, self-contradiction appears, ambivalence of the metaphorical potential and the meaning of the research phenomenon can appear ambiguous. Using the methods of the analysis and comparison, the author aimed at re-analyzing the metaphor as means of the search and reflection of the sense; reflecting its ambivalent character in cases when it is used in the social or epistemological researches; revealing the dual connotation of the metaphorical argumentation in particular philosophical works. Generalized results of the paper can be shown by the following statements: 1) The metaphorical meaning of concepts in social, historical, epistemological practice partly replaces the direct meaning and forms further human culture in a trail from deviation to norm. 2) The concepts "Leviathan" (T. Hobbes), "voice of reason" (J. Locke), "capital" (K. Marx) in metaphorical interpretation form ambivalent historical narratives of criteria of the justice, the truth, the social law and in as such form further human culture. 3) The inner potential of the researches connected with the variety of metaphorical uses is especially important to the sphere of socio-philosophical and socio-political searches.

Key words: metaphor; metaphorical thinking; ambivalence; search for senses; H. Hobbes; J. Locke; K. Marx; "Leviathan"; "voice of reason"; "capital".

Introduction. Hidden metaphorical argumentation is a powerful medium. Its wide use takes place in philosophic, literary, linguistic, psychological researches and practices. One of derivative manifestations of this argumentation may be manipulativity and ambivalence. At the same time, it is worth mentioning that metaphor is so polysemantic and universally used phenomenon that focusing only at its certain aspects would mean predetermined impoverishing of its social or philosophic analysis.

In view of stated problematics of the research, the author considers it necessary to reveal particular aspects of its title. Of course, the conversant specialist would recognize there reminiscences of "Man's search for meaning", cult philosophical work by Viktor Frankl (2014), logotherapy founder, allusion to the "double meanings" that were actualized by John R. Searle (1993) in his work "Metaphor" or to "The logic of sense" by Gilles Deleuze (1990). But in the context of author's treatment of the question it is spoken about self-contradictory character of notional "transfers", which often reveal themselves during the use of metaphors with the purpose of strengthening considerations, cognition, investigation of different phenomena.

The problem of metaphor research have been actual during the whole time of its use. From antiquity to the present time the different aspects of this problem are comprehensively analyzed and investigated. Only last century demonstrated comprehensive search for meaning and significance of the metaphor and its relevance for world philosophical and linguistic discourse. Among the most significant to the author can be named the works of E. Cassirer (1983 [1925]), R. Jakobson (Jakobson and Halle, 1971), J. R. Searle (1993), A. Ortony (1993), G. Lakoff (Lakoff and Johnson, 2003) and many others. The author also determines the works J.Tralau $(2007 ; 2011 ; 2014)$, J. Haflund (2017), K. Kampourakis (2016), J. Halberstam (1995), N. Wolterstorff (1994) such that influenced directly on the conclusion of this paper.

The purpose of the work. The article gives consideration to the ambivalence of the metaphor as medium of meanings by certain examples of its historical and sociophilosophical use.

Presentation of the basic material. Philosophical interpretation of the metaphor begins with Aristotle. In the third book of "Rhetoric" he propounds a thought that the metaphor should help with clarifying and enlightening the common sight in order to disclose it in new better way. For antique rhetoric the metaphor appeared to be a powerful "weapon" of intellectual competitions. The metaphor also 
has the valuable suggestive role. Since antiquity indirect influences on beliefs of recipient were improved constantly and the metaphor had not last role in this process.

The landmarks in innovation development of the metaphorical models in Western philosophy can be outlined exactly with lineage "antiquity- enlightenment-irrationalism". Such are grandiose meta-narratives of preclassical antiquity; metaphorical store of the philosophy of Socrates; Plato's Allegory of the Cave and his metaphorical description of human soul, pathos, mental life; detailed analysis of the role of the metaphor by Aristotle in his "Rhetoric" or his metaphor of father and son created to explain the actor and his actions; related metaphor of master and servant by $\mathrm{G}$. Hegel and his refined metaphor of jump as illustration of dialectical idealism; the great part of philosophy of F. Nietzsche and especially embodied metaphoricalness in truthful overview of his insanity (the Nietzschean horse is imprinted metaphor in itself): the examples of use of metaphors in history of philosophy are countless. Among existing variety we analyze those metaphors that disclose the dual nature of the metaphor and its self-contradictory, ambivalent character the most expressively.

Metaphoricalness of thinking is not certain purposeful approach to the world cognition. In case when the metaphor is understood as merely one kind of tropes, it may produce an impression that the metaphor is only relatively good instrument of transfer or coding the information. It usually appears especially useful in a situation of inexpediency (vs insecurity) of directive (direct) statement or in non-verbal context. Researchers often mention that metaphoric expression is self-contradictory from the beginning, because it leaves its interpretation for the listener or reader (Haglund, 2017; Duit, 1991). The analysis of chain of literary, historical and philosophical primary sources reveals wider field of use, many alternatives that cannot be reduced to vocabulary or speech potential of metaphor.

Using the terminology of Gilles Deleuze, mentioned above, the metaphor appears as cognitive transfer from "codes to axioms" (Deleuze, 1971), from the very meaning to operational categories, functions and rules. However, in this paper author do not consider the metaphor in the coordinates that are laid by Deleuze's works, when the metaphor appears as producer of senses because the reality no longer produces them. The more traditional understanding of the metaphor is used here with intention to demonstrate that under certain conditions it can acquire opposite senses considering the context of use.

Partly, in certain historical, social or intersubjective conditions the metaphor plays the role of codifier of senses as, for example, use of "Aesopian language" or descriptive procedure on pre-philosophical stage of the world reflection. In particular researches the metaphor has function of transgression from metaphysical to epistemological and practical dimension of senses. Plato's "Allegory of the Cave", aphoristic philosophy of Francis Bacon, Friedrich Nietzsche etc., realization of meaningful potential in philosophy of French or Ukrainian Enlightenment can be also named as an example of it. Metaphorical construction of the worldview is always aimed at accessibility to cognition of recipient and in this context appears as flexible instrument of transformation of the meaning into different forms, actually, as certain synergy of substance and form, their unity and effectiveness.

Regardless of dimension in which an analysis of metaphor operation is performed, an important problem of correspondence between the main (directive) meaning of words or sentences and the meaning of speaker's (person who speaks, utters) statement. Such ambivalence was denoted by J. Searle during the analysis of metaphorical statements: "The problem of explaining how metaphors work is a special case of the general problem of explaining how speaker meaning and sentence or word meaning come apart. It is a special case, that is, of the problem of how it is possible to say one thing and mean something else, where one succeeds in communicating what one means even though both the speaker and the hearer know that the meanings of the words uttered by the speaker do not exactly and literally express what the speaker meant" (Searle, 1993: 83-84). So, in opinion of Searle, it is individual case of problem of propositional functions and speech acts.

It is worth to remark the contradictory character of the metaphor as an instrument of cognitive activity. In fact, in the use of the metaphor as means of proving or argumentation the subject of communication should take into consideration ambivalence of reception of recipient. Even realizing the use of this king of trope in communicative act, the recipient would notice one way or another in which sense the given information is the truth. Revaluation or reconsideration of the role of the metaphor partly happens in philosophy. As it happened, for example, in the course if classic English empiricism, representative of which (T. Hobbes, J. Locke) treated with negative to the cognitive potential of the metaphor and were convinced that it could rather darken the truth or cause illusions than clarify or specify. Therewith, in their philosophical work in context of general Enlightenment standard of information transfer, the metaphor transforms into the powerful instrument of giving senses to those who is not capable of understanding the specifics of scientific or philosophical texts. This characteristic of the metaphor is used constantly: "Metaphors make these more comprehensible for non-experts because they are guided to think about them in terms of other phenomena, processes, or mechanisms they are familiar with. However, a major problem that emerges for science education and communication is that it is often very easy to confuse the metaphor with the actual phenomenon. Worse than that, the focus may eventually be on those elements of the actual phenomenon in which the metaphor is better illustrated. As a result, people may overlook other, perhaps important, aspects that do not fit well in the metaphor" (Kampourakis, 2016: 947).

T. Hobbes is the key personality in forming of ambivalence of the metaphor. In "Leviathan" he designates the metaphor as "misuse of the language" (Hobbes and ProQuest (Firm)) that is directed at the listener and considers that the metaphorical use of the words is darkening of their meaning. In Hobbes, the metaphor do not explain the thought, but it also is not very dangerous, as far as it is inconstant and changeable figure of speech. However, it encourages to the absurdity and does not facilitate to the accurate understanding. In the age of deepening the opposition between empiricism and rationalism the great importance is not attached to the metaphor as method of information exchange.

Such attitude is completely predictable in the context of the epoch. In Hobbes opinion, only words can be metaphorical, not perception, bodies or actions (Hobbes and ProQuest (Firm)). In addition, as far as namely the perception and actions appeared as ideal of cognition of New Ages, the cognitive potential of the metaphor could not be overvalued. The metaphor appears as instrument of manifestation of concealed facts and hidden thoughts. However, it also takes the role of substitute of the truth in statements. Obviously, there is the ground to think that 
taking into consideration such sight of the metaphor, Hobbes perceives the danger of the metaphor because it unnoticeably become substitute of thoughts, and then it becomes substitute of conscience, common sense, justice etc. The age of clarification of senses as the main characteristic had the most closely approximation to the truth. The metaphor appeared as the factor of inflaming the weaknesses in process of consideration, because any ambiguity of the words resulted in strengthening of ineligibility of its meaning.

Thus, while the metaphor, in the words of T. Hobbes, is "correspondent misuse" (Hobbes and ProQuest (Firm)), metaphorical expressions cannot stand as full-fledged arguments in communication. Giving the great attention to the analysis of canonical texts and, in particular, the Holy Writ, in his "Leviathan", Hobbes concludes its ambiguous metaphorical character. It should be noted that namely Christian narratives are the basis of forming of European and global standards of human living together, justice, judgment. It seems that Hobbes, explaining ambivalence of this phenomenon, sees the most danger of use of metaphors particularly in their ambiguity. At the same time, they produce canons of things that should be entirely unambiguous and should not admit different meanings: the law and the justice.

Particularly the philosopher insists on the idea that any metaphor has real ground that can be expressed in simple phrases. So, In Hobbes's opinion, there is no meaningful potential to use metaphors as means of representing senses. In such worldview position the reminiscence of Hobbes's worldview to scholastic nominalism with its principles of the saving of thinking is obvious. The historical and philosophical lineage "nominalismempiricism" is obviously manifested also in attitude to the verbal vehicles as instruments of "searching for senses". If the metaphor is widely approved by the Holy Writ, which is nearly the very ground of European worldview, conceptions of justice, judgment, law, the question of standards of interpersonal communication in general is raised on the base of this. And, thereafter, if such communication is aimed at full-fledged mutual understanding. As opposed to the metaphorical worldview that is cherished by Christian canons, there is no place for the metaphor in philosophical texts.

However, Hobbes, who criticized the metaphor resoundingly, gave to his main work the name "Leviathan" at the same time. Taking into consideration meaningful and synonymic connotations of this concept, it would be difficult to avoid the variability of its interpretations. In this example, the ambivalence of the metaphor as way of thinking and senses representation is revealed. So, T. Hobbes, while criticizing the metaphor as a kind of trope, uses its potentialities of senses connotation transmitting, implicit essence reflecting, emotional impact in the recipient. J.Tralau admits that Hobbes do not actually prejudge the metaphor, as it can be considered during the analysis of the fundamental positions of "Leviathan" (Tralau, 2014: 113; Tralau, 2007: 62). According to his words "Hobbes's condemnation of metaphor is so cleverly clad in metaphors as to suggest that Hobbes thinks himself justified in using deceptive metaphors for his own purposes" (Tralau, 2014: 113). In fact, there is a serious contradiction in "Leviathan" between disrespect to the metaphor by Hobbes and his use of it.

Tralau reasonably mentions that a more careful analysis of understanding of the "metaphor" phenomenon in Hobbes works can transform cardinally the general understanding of his philosophy (Tralau, 2014: 113). It is notably that the most uncompromising attitude of Hobbes can be regarded in such parts of his consideration that are about the religious part of the worldview. Though, there are no given examples of clear differentiation between metaphor and comparison, metaphor and allegory. So in some specified sense such uncertainty is beneficial to the philosophy of Hobbes, because it allows to interpret the metaphor as concealed, hidden deception "while analyzing such politic projects that are described in "Leviathan"" (Tralau, 2011: 67). Determining the metaphoric use of the concept as use them in other sense than they are assigned at, or "presentation of one thing with the help of another" Hobbes appeals to such procedure either. By the name of his work Hobbes seems to show all baseness, illusion, deception inherent to the country monster that settles in mind and in fact becomes the criterion of the political morality.

Not only with his politic theory (that, by the way, was not welcomed in England), but with his conceptual view of the metaphor Hobbes influenced greatly on the whole history of philosophy. Among his antecedent there were Plato, Aristotle, N. Machiavelli. His successors and adherents of his ideas are considered to be: J. Locke, G. Hegel, K. Marx, J. S. Mill. Conceptions of many social and politic philosophers of the modern ages are based on his ideas explicitly or implicitly.

J. Locke constructs his view of demonstrability in philosophy on empirical, sensual principles. The major feature of the evidential base of the science is its factivity, its grounding on facts. To strengthen his worldview position Locke repeatedly goes into utterly expressive metaphors. In particular, he uses the metaphor of "wandering in darkness" (wander in darkness, abyss of darkness) to denote the ignorance.

"The ignorance and darkness that is in us no more hinders nor confines the knowledge that is in others, than the blindness of a mole is an argument against the quicksightedness of an eagle" (Locke, 1690) [Book III, Chapter III]. The consciousness that neglects arguments proved in things, the consciousness that ignores principles of demonstrability is doomed to such wander.

"Clearly Locke does not think that we may proceed with whatever evidence we just happen to have. The evidence must be of a quality that makes it satisfactory. And the evidence must consist of things one knows. Belief is to be based on knowledge, on certitude: ideally, on insight. Otherwise it dangles loose and we drift about; or to change the metaphor, otherwise we wander in darkness. Locke's "principle of evidence" as we may call it, can then be formulated as follows" (Wolterstorff, 1994: 183).

To illustrate the confidence in arguments, Locke [Book III, Chapter VII] uses other metaphor - at that point about the necessity of "listening to voice of reason" (Locke, 1690). The probability and the reliability of arguments are directly related to how we trust our rational judgments, to the logical correlation between reality and imagination.

In these metaphors Locke postulates the Enlightenment ideals, accents on the constructive role of criticism in the cognition, but on the other hand the character of these metaphors indicates that the cognitive abilities and resources of mind have some supernatural character for the author. "Wandering in darkness" or "listening to voice of reason" have strict religious connotation that is referred to the concept of the mind as the guide that calls for obedience as God does. The dual and self-contradictory character of the metaphor with obvious reduction to the Biblical senses is revealed there.

In general, prescribed worldview collision is in line with the character of the whole age. "In turn, the fact that Locke's 
philosophical thoughts were focused almost entirely on politics and on epistemology reflects the social and cultural situation of his day (Wolterstorff, 1994: 172). Inasmuch as whole Enlightenment with its deism ideals was rather selfcontradictory, was based on cult of intelligence along with latent, deep religious character, metaphorical arguments of representatives of the age also were represented with essential ambivalent arguments.

In one of the most significant politico-social conceptions in the history of philosophy, the metaphorical dimension of social existence obtains some unexpected realization. K. Marx in "Grundrisse" criticizes the nature of social system by means of use of the metaphor. He describes capitalist social system and British industrialization with the metaphor of a vampire that sucks blood and is guided by mystical dreaming of capital (Marx, 1973: 569). According to Marx, the nature of capital appears ambivalent, one of its sides reflects in chimerical metaphorical characteristic: "The permanence - the duration of value in its form as capital - is posited only through reproduction, which is itself double, reproduction as commodity, reproduction as money, and unity of both these reproduction processes. In its reproduction as commodity, capital is fixated in a particular form of use value, and is thus not general exchange value, even less realized value, as it is supposed to be. The fact that it has posited itself as such in the act of reproduction, the production phase, is proved only through circulation. The greater or lesser perishability of the commodity in which value exists requires a slower or faster reproduction; i.e. repetition of the labour process. The particular nature of use value, in which the value exists, or which now appears as capital's body, here appears as itself a determinant of the form and of the action of capital; as giving one capital a particular property as against another; as particularizing it" (Marx, 1973: 569).

The metaphorical ambivalence becomes obvious when dead labour (Marx) stimulates the powerful motion of capitalism. Marx, in fact, is describing an economic system, capitalism, which is positively Gothic in its ability to transform matter into commodity, commodity into value, and value into capitalism (Halberstam, 1995: 102-103). The way in which Marx elaborated an idea of alienation through the work, described destructive jaws of capitalism growth conditions by means of trampling on personality, paralyzing influence on the person, in some specified sense provoked an idea of transgressive subject. This is the core idea of existential- absurd model of the world perception in $\mathrm{XX}$ century from Kafka to Baudrillard and it is also filled with metaphorical searching for senses. However, this idea is the subject of other scientific researches. In this metaphor, that is used by K. Marx to illustrate capitalism, self-contradictory, ambivalent and, at the same time, demonic character of social laws, which are originated as deviations and gradually gain the character of norm reconciled by everyone, is reflected.

In conclusion, it can be established that ambivalent character of the sense between the directive meaning and its metaphorical expression is rather repeated phenomenon in the philosophy. Considering this, further explorations of it could be proceeded.

\section{Conclusion}

The inner potential of researches connected with the difference of metaphorical use is the most essential to the sphere of socio-philosophical and socio-political searching. In empirical researches the potential of the metaphor is insignificant so far as it results in few widening of concepts in their strict sense. However, in social researches namely metaphorical character of the subject of investigation plays center stage, and sometimes it impoverishes the main (directive) meaning. The internal contradiction emerges here, ambivalence of metaphorical potential and sense of investigated phenomenon can appear as ambiguous. Moreover, this ambiguity may generate further ambivalent historical narratives. "Leviathan" by T. Hobbes, "Voice of reason" by J. Locke, "Capital" by K. Marx may be referred to them. In metaphorical meaning these are concepts that characterize the country as the evil machine, "divine" voice of reason as way to the truth, the capital as the demonic law of social development. Actually, in such meaning these concepts are forming further human culture and obtaining the character of criteria of the justice, the truth, the social law, blazing a trail from deviation to norm.

\section{REFERENSES}

Aristotle (350 B.C.E). Rhetoric. Translated by W. Rhys Roberts. Retrieved from http://classics.mit.edu/Aristotle/rhetoric.html (In English).

Cassirer, E. (1983 [1925]). Sprache und Mythos: Ein Beitrag zum Problem der Götter-namen. Philosophie der symbolischen Formen. Darmstadt: Wissenschaftliche Buchgesellschaft. (In German).

Deleuze, G. (1971). Capitalism, flows, the decoding of flows, capitalism and schizophrenia, psychoanalysis, Spinoza. AntiOedipus: Capitalism and Schizophrenia (2) Mille plateaux. (In English).

Deleuze, G. (1990). The logic of sense. New York: Columbia University Press. (In English).

Duit, R. (1991). On the role of analogies and metaphors in learning sciences. Science Education, 75(6): 649-672. DOI: https:/ /doi.org/10.1002/sce.3730750606 (In English).

Frankl, V. E. (2014). Man's search for meaning. Boston: Beacon Press (In English).

Haglund, J. (2017). Good Use of a 'Bad' Metaphor. Entropy as Disorder. Science \& Education, 26 (3-4), pp. 205-214. DOI: https:/ /doi.org/10.1007/s11191-017-9892-4 (In English).

Halberstam, J. (1995). Skin Shows: Gothic Horror and the Technology of Monsters. Durham, NC: Duke University Press (In English)

Hobbes, T. \& ProQuest (Firm). Leviathan: the matter, forme \& power of a common-wealth ecclesiastical and civill (In English). Jakobson, R. \& Halle, M. (1971). Fundamentals of language, $2 \mathrm{~d}$ revised, The Hague: Mouton (In English).

Kampourakis, K. (2016). The Bad Use of Metaphors and the Use of Bad Metaphors. Science \& Education, 25(9-10), pp. 947949. DOI: https://doi.org/10.1007/s11191-016-9870-2 (In English). Lakoff, G. \& Johnson, M. (2003). Metaphors we live by. Chicago, III.; London: University of Chicago Press (In English).

Locke, J. (1690). An essay concerning humane understanding. In four books. London: Printed for Tho. Basset, and sold by Edw. Retrieved from ftp://ftp.dca.fee.unicamp.br/pub/docs/ia005/ humanund.pdf (In English).

Marx, K. (1973). Grundrisse. Foundations of the Critique of Political Economy (Rough Draft).

Ortony, A. (1993). Metaphor and thought, 2nd, Cambridge England; New York, NY, USA: Cambridge University Press (In English).

Searle, J. R. (1993). Metaphor. In: Ortony, A. (ed.) Metaphor and Thought. Cambridge: Cambridge University Press (In English).

Tralau, J. (2007). Leviathan, the Beast of Myth Medusa, Dionysos, and the Riddle of Hobbes's Sovereign Monster. In: Springborg, P. (ed.) The Cambridge Companion to Hobbes's Leviathan. New York: Cambridge University Press. (In English).

Tralau, J. (2011). Hobbes contra Liberty of Conscience. 
Political Theory, 39(1), pp. 58-84. DOI: https://doi.org/10.1177/ 0090591710386698 (In English).

Tralau, J. (2014). Deception, politics and aesthetics: The importance of Hobbes's concept of metaphor. Contemporary Political Theory, 13(2), pp. 112-129.

Wolterstorff, N. (1994). Locke's philosophy of religion. The Cambridge companion to Locke. UK: Cambridge University Press.

\section{LIST OF REFERENCE LINKS}

Frankl V. Man's search for meaning. E.Boston: Beacon Press, 2014. XVI, $182 \mathrm{p}$

Searle J. R. Metaphor. Metaphor and Thought / Ortony A. (ed.). Cambridge: Cambridge University Press, 1993. Pp. 83-111.

Deleuze G. The logic of sense. European perspectives. New York: Columbia University Press, 1990. European perspectives. XIV, $393 p$

Cassirer E. Sprache und Mythos: Ein Beitrag zum Problem der Götter-namen. Philosophie der symbolischen Formen. Darmstadt: Wissenschaftliche Buchgesellschaft, 1983 [1925]. S. 71-167.

Jakobson R. Fundamentals of language. Janua linguarum Series minor. Halle M.2d revised. The Hague: Mouton, 1971. T. 1: Janua linguarum Series minor. $96 \mathrm{p}$.

Ortony A. Metaphor and thought. 2nd изд. Cambridge England; New York, NY, USA: Cambridge University Press, 1993. XVI, $678 \mathrm{p}$.

Lakoff G., Johnson M. Metaphors we live by. Chicago, III.; London: University of Chicago Press, 2003.

Tralau J. Leviathan, the Beast of Myth Medusa, Dionysos, and the Riddle of Hobbes's Sovereign Monster. The Cambridge Companion to Hobbes's Leviathan. Springborg P. New York: Cambridge University Press, 2007. Pp. 61-81.

Tralau J. Hobbes contra Liberty of Conscience. Political Theory. 2011. T. 39, № 1. Pp. 58-84.
Tralau J. Deception, politics and aesthetics: The importance of Hobbes's concept of metaphor. Contemporary Political Theory. 2014. T. 13, № 2. Pp. 112-129.

Haglund J. Good Use of a 'Bad' Metaphor. Entropy as Disorder. Science \& Education. 2017. T. 26, № 3-4. Pp. 205-214.

Kampourakis K. The Bad Use of Metaphors and the Use of Bad Metaphors. Science \& Education. 2016. T. 25, № 9-10. Pp. 947-949.

Halberstam J. Skin Shows: Gothic Horror and the Technology of Monsters. Durham, NC: Duke University Press, 1995.

Wolterstorff N. Locke's philosophy of religion. The Cambridge companion to Locke. UK: Cambridge University Press, 1994. Pp. 172-199.

Aristotle (350 B.C.E). Rhetoric / Translated by W. Rhys Roberts. URL: http://classics.mit.edu/Aristotle/rhetoric.htm

Duit $\mathrm{R}$. On the role of analogies and metaphors in learning sciences. Science Education.1991. T. 75, № 6. Pp. 649-672.

Deleuze G., Capitalism, flows, the decoding of flows, capitalism and schizophrenia, psychoanalysis, Spinoza. Anti-Oedipus: Capitalism and Schizophrenia. Mille plateaux, 1971. URL: https:/ /www.webdeleuze.com/textes/116.

Hobbes T. ProQuest (Firm). Leviathan: the matter, forme \& power of a common-wealth ecclesiastical and civill. URL: http:// ebookcentral. proquest.com/lib/abdn/detail.action?doc ID $=441243$.

Locke J. An essay concerning humane understanding. In four books. Printed for Tho. Basset, and sold by Edw., 1690. URL: http://www.gutenberg.org/files/10615/10615-h/10615-h.htm, http:/ /www.gutenberg.org/cache/epub/10616/pg10616-images.html.

Marx K. Grundrisse. Foundations of the Critique of Political Economy (Rough Draft). 1973. (HTML Mark-up: Andy Blunden, 2002; Dave Allinson, 2015).

Стояцька Ганна,

Дніпропетровський державний університет внутрішніх справ (м. Дніпро, Украӥна)

e-mail: a.sagdianna@gmail.com,ORCID 0000-0002-6501-6703

\section{АМБІВАЛЕНТНІСТЬ МЕТАФОРИЧНОГО МИСЛЕННЯ У КОНТЕКСТІ ПОШУКУ СМИСЛІВ}

У даній статті піднімається питання амбівалентного характеру метафори як певного способу вираження смислу. Автор на прикладах функціонування соціальних метафор у роботах Т. Гоббса, Дж. Локка, К. Маркса показує, що вони можуть бути концептуально переосмислені з огляду на контекст вживання. В залежності від такого контексту виникає внутрішнє протиріччя, амбівалентність метафоричного потенціалу і сенс досліджуваного явища може поставати неоднозначним. Використовуючи методи аналізу та порівняння, автор прагнула досягти наступної мети: здійснити ре-аналіз метафори як засобу пошуку та відображення смислу; продемонструвати її амбівалентний характер у тих випадках, коли вона використовується для соціального або епістемологічного дослідження; розкрити дуальні конотації метафоричної аргументації в окремих філософських творах. Узагальнені результати, отримані у статті, можна завести до наступних положень: 1) Метафоричне значення понять в соціальній, історичній, епістемологічній практиці почасти замінює пряме, директивне значення i формує подальшу культуру людства у напрямку від девіації до норми. 2) Поняття "Leviathan" (T. Гоббc), "voice of reason" (Дж. Локк), "capital" (К. Маркс) у метафоричній інтерпретації породжують амбівалентні історичні наративи щодо критеріїв справедливості, істини, соціального закону і в такому вигляді формують подальшу культуру людства. 3) Внутрішній потенціал досліджень, пов'язаних з різноманітністю метафоричних вживань, є особливо значним для сфери історико-філософських та соціально-політичних пошуків.

Ключові слова: метафора; метафроричне мислення; амбівалентність; пошук смислу; Т. Гоббс; Дж. Локк; К. Маркс; "Левіафран"; "голос розуму"; "капітал".

(C) Stoyatska Ganna

Надійшла до редакції: 26.12.2018

Прийнята до друку: 21.02.2019 